\title{
prosthetics
}

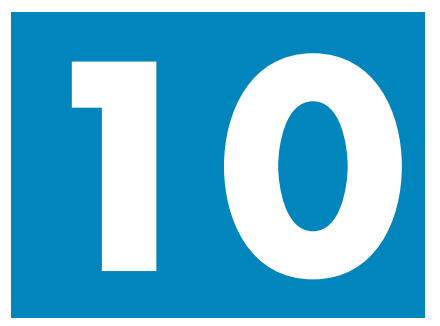

\section{Identification of complete denture problems: a summary}

\author{
J. F. McCord, ' and A. A. Grant, ${ }^{2}$
}

\section{In this section, guidelines to the diagnosis of complete denture problems are presented in tabular form. Suggestions to the management of these problems are listed.}

In this part, we will discuss:

- Factors resulting in discomfort associated with dentures

- Factors resulting in looseness of the dentures

- Factors associated with problems of adaptation
$1^{*}$ Head of the Unit of Prosthodontics,

${ }^{2}$ Emeritus Professor of Restorative

Dentistry, University Dental Hospital of Manchester, Higher Cambridge Street, Manchester M15 6FH

${ }^{*}$ Correspondence to: Prof. J. F. McCord email:Learj@fs1.den.man.ac.uk REFEREED PAPER

(c) British Dental Journal

2000; 189: 128-134
$\mathrm{T}$ here is, inevitably, the potential for problems 1 to arise subsequent to the insertion of complete dentures. These problems may be transient and may be essentially disregarded by the patient or they may be serious enough to result in the patient being unable to tolerate the dentures.
Factors causing problems may be grouped, essentially into four causes.

- Adverse intra-oral anatomical factors eg atrophic mucosa.

- Clinical factors eg poor denture stability.

- Technical factors eg failure to preserve the
Symptoms/clinical findings

Related to impression surface Discrete painful areas

Pain on insertion and removal, possibly inflamed mucosa on side(s) of ridges

Areas painful to pressure

Over-extension of lingual flange. Painful mylohyoid ridge; denture lifts on tongue protrusion; painful to swallow

Generalised pain over denture-supporting area

Lack of relief for frena or muscle attachments; pinching of tissue between denture base and retromolar pad or tuberosity. Sore throat, difficulty in swallowing

\section{Cause}

Pearls or sharp ridges of acrylic on the fitting surface arising from deficiency in laboratory finishing

Denture not relieved in region of undercuts

Pressure areas resulting eg from faulty impressions, damage to working cast, warpage of denture base. Consider also residual pathology (eg retained root), lack of relief for active frena, non-displaceable mucosa over bony prominence (eg torus)

Over-extended lower impression: instructions to laboratory not clear or non-existent

Under-extended denture base - may be the result of over-adjustment to the periphery, or impression surface. Check for adequacy of FWS

Peripheral over-extension resulting from impression stage and/or design error. Palatal soreness as post dam too deep

\section{Treatment}

Locate with finger, or snagging dry cotton wool fibres. Use disclosing material to assist locality to ease denture

Use disclosing material to adjust in region of 'wipe off'. Exercise care as excessive removal may reduce retention. Also clinician should only insert denture and then remove it - the patient should not occlude as this may confuse an occlusal fault with support problems

Use disclosing material to accurately locate area to be relieved. If severe, remake may be required. Consider removal of root

Determine position and extent of over-extension using disclosing material and relieve accordingly

Extend denture to optimal available denture support area. If insufficient FWS, remake may be required

Relieve with aid of disclosing material. Care with adjustment of post dam - removal of existing seal and its replacement in greenstick prior to permanent addition may be required 


\begin{tabular}{|c|c|c|}
\hline $\begin{array}{l}\text { Related to occlusal surfaces } \\
\text { Pain on eating in presence of occlusal } \\
\text { imbalance (no support problems) }\end{array}$ & $\begin{array}{l}\text { Anterior prematurity or posterior prematurity, } \\
\text { incisal locking, lack of balanced articulation }\end{array}$ & $\begin{array}{l}\text { Determine where occlusal prematurities exist. } \\
\text { Adjust occlusion by selective grinding. If severe } \\
\text { error remount using facebow and new } \\
\text { interocclusal records }\end{array}$ \\
\hline Pain lingual to lower anterior ridge & $\begin{array}{l}\text { If no over-extension present, look for } \\
\text { protrusive slide from RCP to ICP }\end{array}$ & $\begin{array}{l}\text { Mark deflecting inclines of posterior teeth with thin } \\
\text { articulating paper. If slide exceeds half a cusp } \\
\text { width, re-register and reset }\end{array}$ \\
\hline $\begin{array}{l}\text { Pain and/or inflammation on labial aspect of } \\
\text { lower ridge }\end{array}$ & $\begin{array}{l}\text { If no impression surface defect, may be lack } \\
\text { of incisal overjet causing incisal locking }\end{array}$ & $\begin{array}{l}\text { Reduce incisal vertical overlap. If appearance } \\
\text { compromised, resetting the incisors may be } \\
\text { required }\end{array}$ \\
\hline Cheek and or lip biting & $\begin{array}{l}\text { For cheeks - likely that functional width of } \\
\text { sulcus was not restored. } \\
\text { For lips - poor lip support/inadequate } \\
\text { anterior horizontal overlap }\end{array}$ & $\begin{array}{l}\text { For cheek biting, restore functional width of sulcus } \\
\text { and/or reset. For lips, grind lower incisors to } \\
\text { provide a more appropriate incisal guidance } \\
\text { angle }\end{array}$ \\
\hline Tongue biting & $\begin{array}{l}\text { Lack of lingual overjet - teeth generally } \\
\text { placed lingual to lower ridge }\end{array}$ & Remove lower lingual cusps, or reset teeth \\
\hline $\begin{array}{l}\text { Related to polished surfaces } \\
\text { Pain at posterior aspect of upper denture on } \\
\text { opening }\end{array}$ & $\begin{array}{l}\text { Flange on buccal aspect of tuberosity too } \\
\text { thick and constraining coronoid process }\end{array}$ & $\begin{array}{l}\text { Use disclosing material to accurately define area } \\
\text { involved, relieve and repolish }\end{array}$ \\
\hline
\end{tabular}

peripheral roll on a master cast.

- Patient adaptional factors.

By far the most critical factors are the patient adaptional factors. Many patients with positive stereotypes may overcome errors of prescription. Some patients, however, are unable to adapt physically and/or psychologically to dentures that satisfy clinical and technical prosthodontic norms. Clearly it would be in the best interests of the clinician and the patient to determine this at the assessment stage, and was referred to in Part 2.

The prescribing clinician is responsible for planning complete dentures after diagnosing potential problems; be they anatomical, physiological, pathological or emotional.

Once a denture-wearing problem becomes apparent, it is important that it is addressed in a logical and systematic way. That is to say, an adequate history of the problem must be obtained and a careful examination of the mouth carried out so that an accurate diagnosis can be made, and an appropriate treatment plan devised.

Without doubt listening to the patient (as their difficulties are described) is the most important first step in the process, and its importance cannot be overemphasised.

Because of the plethora of potential complete denture problems, this section is largely confined to those that are most commonly encountered at the time of insertion of replacement dentures or during review appointments in the days and weeks after insertion. For a comprehensive overview of the diagnosis and management of complete denture problems, readers are referred to 


\section{PRACTICE prosthetics}

\section{Symptoms/clinical findings}

Burning sensation over upper denture supporting tissues, but may involve other intra-oral tissues, eg tongue.

Beefy red tongue, possibly glossodynia

Frictional lesions related to dentures, mucosa may adhere to probing finger may be complaint of dry mouth

Tongue thrusting. Empty mouth 'chewing'. Often seen in elderly patients

Presence of herpetiform ulcers in mouth

Painful 'click' related to TMJ on opening and/or closing mouth and/or tenderness of muscles of mastication

Patient complains of allergy to denture material

Painless erythema of mucosa related to support of (usually) upper denture, may be accompanied by angular cheilitis

\section{Cause}

Burning mouth syndrome often seen in middle-aged or elderly females. Denture

faults must be excluded, also general organic and pyschogenic factors

Vitamin $\mathrm{B}$ /2/folate deficiency

Xerostomia, commonly side effect of prescribed drugs

May have neurological or psychological aspects. Possibly drug related

Herpes simplex or Herpes zoster virus. History and distribution of lesions to confirm

TMJ pain dysfunction syndrome may be related to rapid change on OVD (either gross increase or decrease) on production of new denture. May have psychological aspects, occasionally part of general joint disease

Rare symptoms may relate to higher residual monomer content of acrylic

Denture-related stomatitis. Often has a frictional element due to ill-fitting denture plus opportunistic candidal infection. Occasionally related to iron or folate deficiency

\section{Treatment}

Correction of any denture faults, may require multivitamin/nutrition advice and treatment.

Possibly antidepressant therapy. Refer to Consultant in Oral Medicine

Refer for medical treatment

Where some saliva flow is present, sugar-free citrus lozenges may help. Where there is an obvious paucity of saliva, artificial saliva may be considered

Difficult to manage. Treatment may be required to include occlusal adjustment and/or occlusal pivots

Dentures merely coincidental to the condition. May be useful to suggest preventive remedy (eg acyclovir) for some sufferers

If denture faults present, careful correction required with special care to registration and vertical dimension

If excess residual monomer detected, rebase denture using controlled heat cure cycle. May need to consider remaking denture using polycarbonate resin

Best to leave denture out until condition clears then remake. If not possible, correct denture faults, eg using occlusal pivots, regularly supervised and replaced tissue conditioners prior to remake. If angular cheilitis present, combinations of antifungal and antibacterial agents (eg miconazole) useful standard prosthodontic texts.

Problems reported by patients shortly after provision of replacement dentures include discomfort, looseness or general problems in relation to adaptation. Some of these problems/difficulties may have a very large number of possible causes, and, indeed, can be multifactorial in origin. For simplicity the problems will be discussed in the order they tend to occur most frequently.

In the following tables, a list of causes and suitable forms of treatment to address the problems are summarised.

\section{Discomfort associated with dentures}

Many patients experience some discomfort for a period of up to a few days following receipt of new or replacement dentures. The great majority of patients achieve comfortable co-existence with their appliances following a short period of adjustment to the new conditions. This can be greatly assisted by a careful, detailed explanation of any difficulties that the operator might anticipate.

For some, however, especially where potential problems were not identified at examination or at the time of insertion, the consequent 


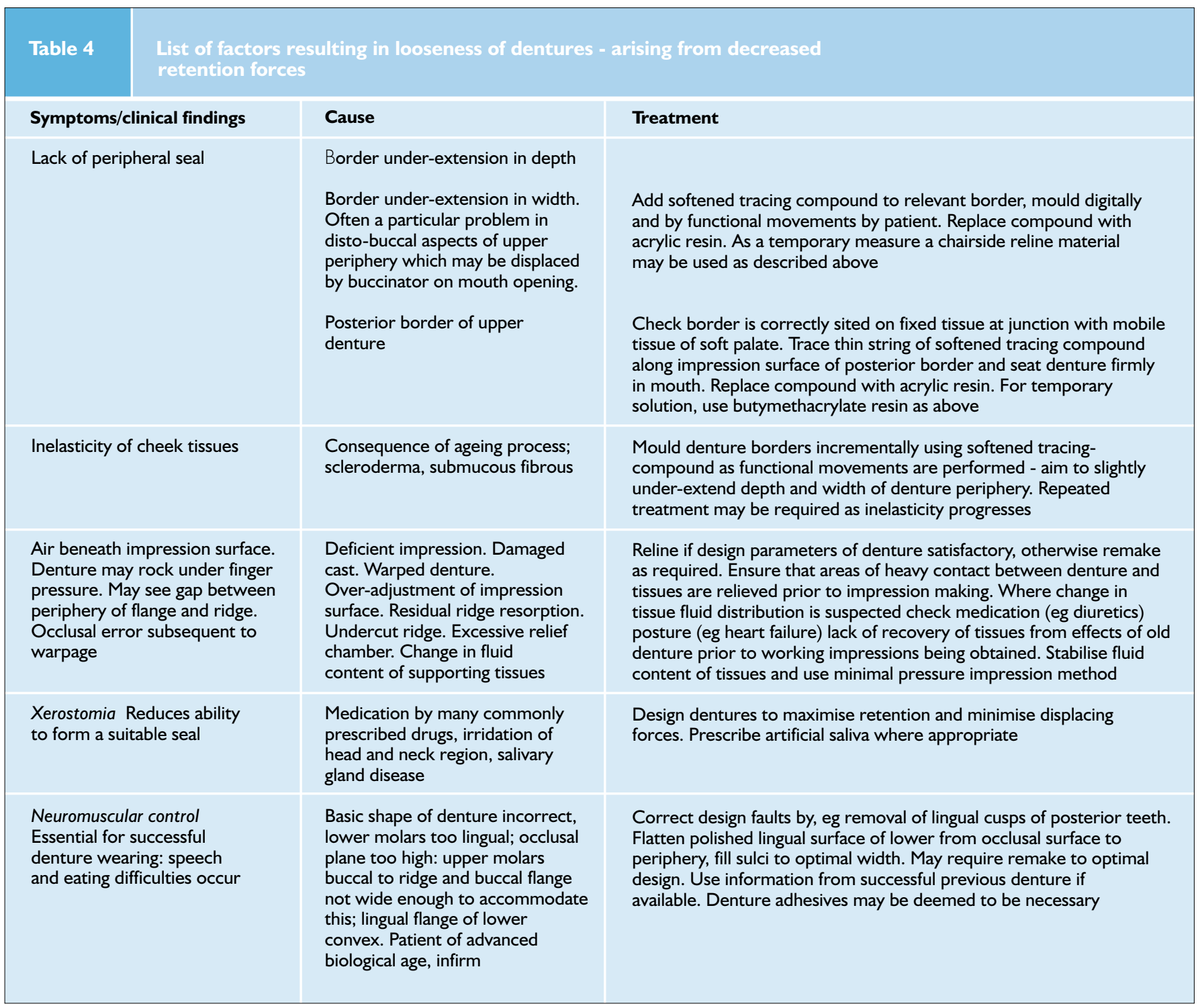

discomfort can be prolonged.

In addition, discomfort may arise some time after apparently successful prosthodontic provision as a result of intra-oral or systemic changes or of denture wear or damage. Discomfort is most frequently - but not exclusively - associated with the lower denture supporting area.

The Tables (Tables 1, 2 and 3) summarise commonly experienced sources of discomfort, and means of addressing the causative factors.

\section{Looseness of dentures}

Looseness of dentures (Tables 4, 5 and 6) is more commonly associated with the lower denture, and may be referred to by patients as their denture 'rocking', 'falling' (complete upper) or 'rising' (complete lower), 'shifting' or sometimes that they 'feel too big'.

In simple terms, retention and stability of complete dentures may be likened to a simple balance ie on one side retaining forces and on the other displacing forces. If the latter exceed the former, instability/looseness will arise. It 


\section{PRACTICE prosthetics}

\begin{tabular}{|c|c|c|}
\hline \multicolumn{3}{|c|}{$\begin{array}{l}\text { List of factors resulting in looseness of dentures: arising from increased } \\
\text { displacing forces }\end{array}$} \\
\hline Symptoms/clinical findings & Cause & Treatment \\
\hline $\begin{array}{l}\text { Denture borders } \\
\text { Over-extension in depth } \\
\text { Slow rise of lower denture when } \\
\text { mouth half open, line of } \\
\text { inflammation at reflection of sulcal } \\
\text { tissues; ulceration in sulcal region. } \\
\text { Deep post dam on upper base } \\
\text { may cause pain, ulceration }\end{array}$ & $\begin{array}{l}\text { If buccal to tuberosities, denture } \\
\text { displaces on mouth opening, or } \\
\text { cheek soreness occurs. Thickened } \\
\text { lingual flange enables tongue to } \\
\text { lift denture; thick upper and lower } \\
\text { labial flanges may produce } \\
\text { displacement during muscle } \\
\text { activity }\end{array}$ & $\begin{array}{l}\text { Slightly under-extend denture flange } \\
\text { and accurately mould softened } \\
\text { tracing compound. Check borders } \\
\text { of record rims and trial dentures at } \\
\text { the appropriate stages. Deep post } \\
\text { dam to be cautiously reduced and } \\
\text { denture worn sparingly until } \\
\text { inflammation clears }\end{array}$ \\
\hline $\begin{array}{l}\text { Overextension in width } \\
\text { Cheeks appear plumped out. In } \\
\text { lower, the buccal flange may be } \\
\text { palpated lateral to external } \\
\text { oblique ridge }\end{array}$ & Design error & $\begin{array}{l}\text { Reduce over-extension. Use } \\
\text { disclosing material to determine } \\
\text { what is excessive }\end{array}$ \\
\hline $\begin{array}{l}\text { Poor fit to supporting tissue } \\
\text { Recoil of displaced tissue lifts } \\
\text { denture }\end{array}$ & $\begin{array}{l}\text { Poor/inappropriate impression } \\
\text { technique especially in posterior } \\
\text { lingual pouch area }\end{array}$ & $\begin{array}{l}\text { Reline if all other design parameters } \\
\text { satisfactory, otherwise remake. } \\
\text { Ensure denture is removed from } \\
\text { mouth } 90 \text { mins prior to impression }\end{array}$ \\
\hline Denture not in optimal space & $\begin{array}{l}\text { Molars on lower denture lingual } \\
\text { to ridge, optimum triangular } \\
\text { shape of dentures absent } \\
\text { Posterior occlusal table too } \\
\text { broad, causing tongue trapping } \\
\text { Thick lingual flanges encroaching } \\
\text { on tongue space, causing lifting. } \\
\text { Excess lip pressure to lower } \\
\text { anterior aspect - teeth anterior } \\
\text { to ridge, thick periphery } \\
\text { Excess pressure from upper lip to } \\
\text { upper denture arising from teeth } \\
\text { too labially sited to acute } \\
\text { naso-labial angle; or failure to } \\
\text { adequately seat denture during } \\
\text { relining impression procedure }\end{array}$ & $\begin{array}{l}\text { Remove lingual cusps and lingual } \\
\text { surface from relevant area, repolish. } \\
\text { If triangular form not restored, reset } \\
\text { teeth or remake dentures } \\
\text { Narrow posterior teeth and/or } \\
\text { remove most distal teeth from } \\
\text { dentures. Reshape lingual polished } \\
\text { surface } \\
\text { Thin lower labial flange, ensure } \\
\text { optimal extension to retromolar } \\
\text { pads to resist displacement, reset } \\
\text { anterior teeth if necessary } \\
\text { Usually requires remaking denture }\end{array}$ \\
\hline
\end{tabular}

must be stressed, however, that the fulcrum is the patient, or rather the patient's ability to adapt to dentures - this is less easy to anticipate. This is illustrated in Figure 1, which is a line drawing of factors influencing complete denture stability.

\section{Problems relating to an inability to adapt to dentures}

There are a variety of symptoms which may be functionally-related (ie eating associated prob-

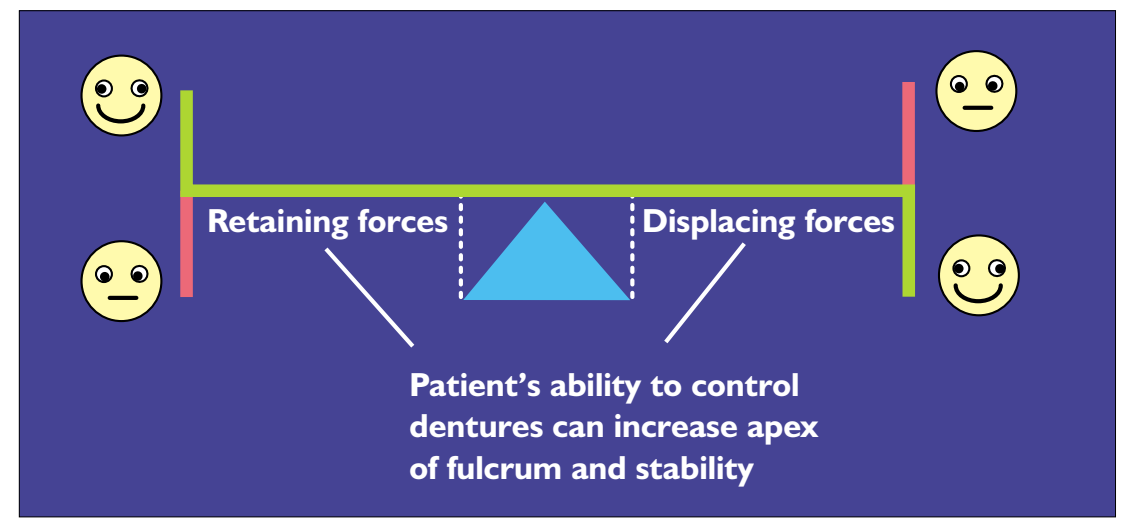

Fig. 1 Factors influencing complete denture stability 


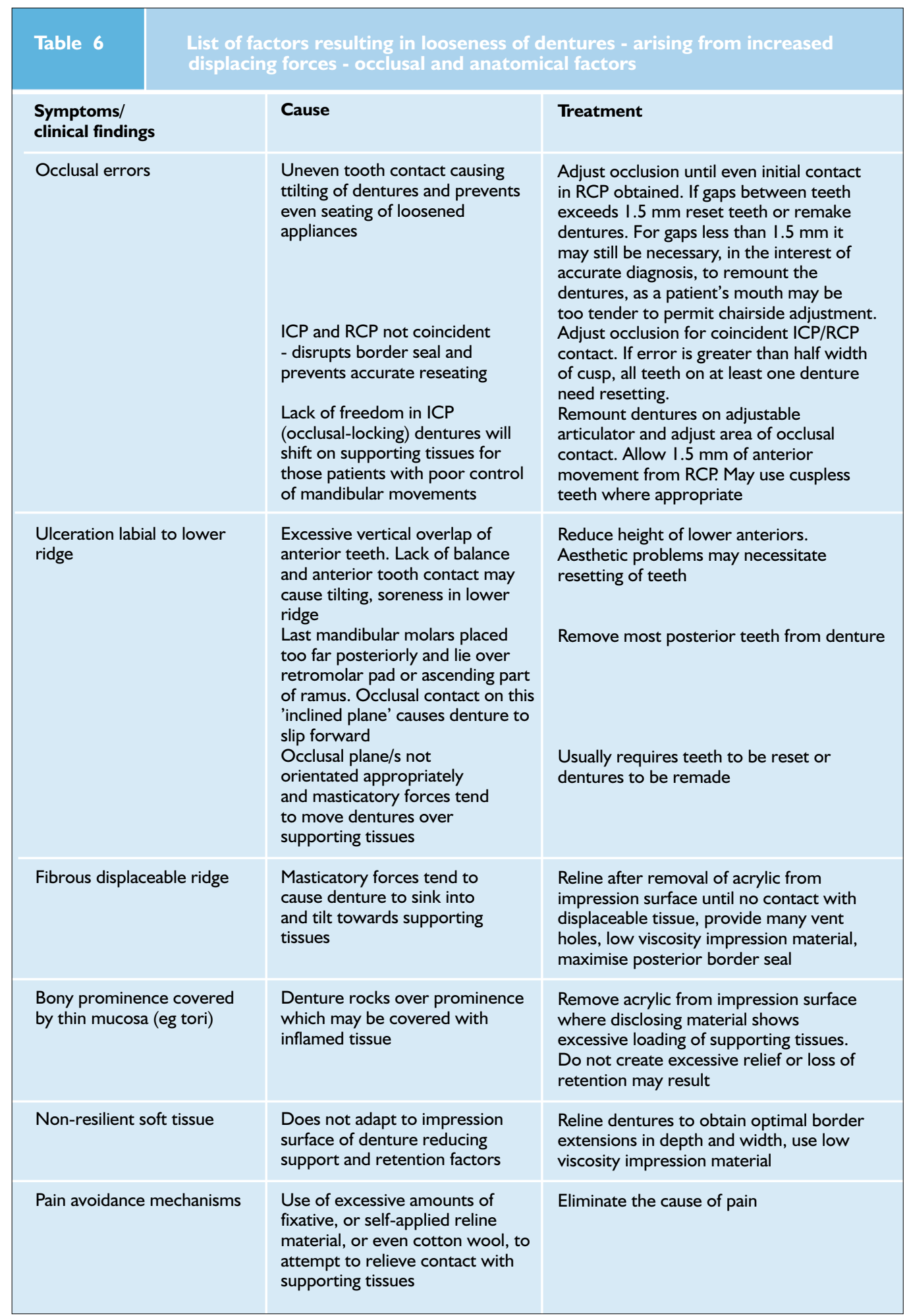

lems, speech etc), psychologically-related or may relate to patience. Clearly there is a need to diagnose the former at the planning stage of treatment and to avoid the latter by virture of trial denture visits which focus on the functional and aesthetic components of the compete dentures.

Some of the psychologically-related problems may be recognised at an early stage but even if psychological assessments are taken, not all are infallible.
A brief list of factors affecting adaptation to dentures including their causes and modes of treament are listed in Table 7.

\section{Summary}

This chapter has attempted to summarise in a tabular form a list of factors that are commonly found at recall visits. The tables themselves are self-explanatory and serve as a 'useful tip' list.

For more detailed lists, readers are referred to standard prosthodontic text. 


\section{PRACTICE prosthetics}

\begin{tabular}{|c|c|c|}
\hline List of denture pro & associated with problems of ada & \\
\hline Symptoms/clinical findings & Cause & Treatment \\
\hline $\begin{array}{l}\text { Noise on eating/speaking } \\
\text { May be apparent on first insertion } \\
\text { or may appear as resorption } \\
\text { causes dentures to loosen }\end{array}$ & $\begin{array}{l}\text { May be lack of skill with new } \\
\text { dentures, excessive OVD, occlusal } \\
\text { interference, loose dentures, or } \\
\text { poor perception of patient to } \\
\text { denture wearing }\end{array}$ & $\begin{array}{l}\text { Where unfamiliarity present, } \\
\text { reassurance and persistence } \\
\text { recommended. Address specific } \\
\text { faults or remake as required }\end{array}$ \\
\hline $\begin{array}{l}\text { Eating difficulties } \\
\text { Dentures move over supporting } \\
\text { tissues }\end{array}$ & $\begin{array}{l}\text { Unstable dentures. Check that } \\
\text { retentive forces are maximised } \\
\text { and displacing forces minimised } \\
\text { and all available support has been } \\
\text { used }\end{array}$ & $\begin{array}{l}\text { Construct dentures to maximise } \\
\text { retention and minimise displacing } \\
\text { forces }\end{array}$ \\
\hline 'Blunt teeth' & $\begin{array}{l}\text { Broad posterior occlusal surfaces } \\
\text { which replaced narrow teeth on } \\
\text { previous denture. Non anatomical } \\
\text { type teeth used where cusped teeth } \\
\text { previously used }\end{array}$ & $\begin{array}{l}\text { Where non-anatomical teeth used, } \\
\text { careful explanation of rationale is } \\
\text { required, may be possible to } \\
\text { reshape teeth. Routine use of } \\
\text { narrow tooth moulds recommended. }\end{array}$ \\
\hline 'Jaws close too far' & $\begin{array}{l}\text { Lack of OVD, so that mandibular } \\
\text { elevator muscles cannot work } \\
\text { efficiently }\end{array}$ & $\begin{array}{l}\text { May increase up to } 1.5 \mathrm{~mm} \text { by } \\
\text { relining but if deficiency is greater, } \\
\text { remake denture }\end{array}$ \\
\hline $\begin{array}{l}\text { 'Cannot open mouth wide enough } \\
\text { for food'. May be speech } \\
\text { problems and facial pain } \\
\text { especially over masseter region }\end{array}$ & Excessive OVD & $\begin{array}{l}\text { Can remove up to } 1.5 \mathrm{~mm} \text { from } \\
\text { occlusal plane by grinding, but if } \\
\text { more is required, remake dentures }\end{array}$ \\
\hline $\begin{array}{l}\text { Speech problems } \\
\text { Uncommon, but presence is of } \\
\text { great concern to patient. May } \\
\text { affect sibilant (eg s), bilabial } \\
\text { (eg p,b), labiodental (eg f.v) }\end{array}$ & $\begin{array}{l}\text { Cause may not be obvious. May } \\
\text { be unfamiliarity - check that } \\
\text { problem not present with old } \\
\text { dentures }\end{array}$ & $\begin{array}{l}\text { Check for vertical dimension } \\
\text { accuracy, and that vertical incisor } \\
\text { overlap not excessive. Palatal } \\
\text { contour should not allow excessive } \\
\text { tongue contact or air leakage - } \\
\text { assess using disclosing paste over } \\
\text { denture palate while sound is made. } \\
\text { NB It is recommended that the } \\
\text { patient's speech is assessed at trial } \\
\text { insertion visit }\end{array}$ \\
\hline $\begin{array}{l}\text { Gagging } \\
\text { May be volunteered by patient } \\
\text { prior to treatment, or apparent at } \\
\text { commencement of treatment or on } \\
\text { insertion of denture }\end{array}$ & $\begin{array}{l}\text { May be loose dentures, thick distal } \\
\text { border of upper denture: lingual } \\
\text { placement of upper posterior teeth } \\
\text { or low occlusal plane causing } \\
\text { contact with dorsal aspect of } \\
\text { tongue }\end{array}$ & $\begin{array}{l}\text { Construct dentures to maximise } \\
\text { retention and minimise displacing } \\
\text { forces. Use 'condition' appliance } \\
\text { eg fully extended base for home } \\
\text { use. Psychological assessment if } \\
\text { indicated }\end{array}$ \\
\hline $\begin{array}{l}\text { Appearance } \\
\text { Complaints may arise from patient } \\
\text { or relatives. Common complaints } \\
\text { include: shade of teeth too light or } \\
\text { dark; mould too big/small; } \\
\text { arrangement too even or irregular } \\
\text { or lacking diastema }\end{array}$ & $\begin{array}{l}\text { Patient failed to comment at trial } \\
\text { stage, or has subsequently been } \\
\text { swayed by family or friends. } \\
\text { Perhaps the change from the old } \\
\text { denture to the replacement denture } \\
\text { is too sudden/severe }\end{array}$ & $\begin{array}{l}\text { Accurate assessment of patient's } \\
\text { aesthetic requirements. Ample time } \\
\text { for patient comments at trial stage. } \\
\text { Use any available evidence to } \\
\text { assist - photographs, previous } \\
\text { dentures. Consider template } \\
\text { prosthesis }\end{array}$ \\
\hline Too much visibility of teeth & $\begin{array}{l}\text { Level of occlusal plane } \\
\text { unacceptable, teeth placed on } \\
\text { upper anterior ridge and no/poor } \\
\text { lip support }\end{array}$ & $\begin{array}{l}\text { Accurate prescription to laboratory } \\
\text { via optimally adjusted occlusal rim }\end{array}$ \\
\hline Creases at corners of mouth & $\begin{array}{l}\text { Labial fullness and anterior tooth } \\
\text { position may be inaccurate. OVD } \\
\text { may be inadequate }\end{array}$ & $\begin{array}{l}\text { Adjust tooth position as appropriate. } \\
\text { If OVD problem, re-register jaw } \\
\text { relations }\end{array}$ \\
\hline $\begin{array}{l}\text { Colour of denture base material } \\
\text { 'unnatural' }\end{array}$ & $\begin{array}{l}\text { Patient's skin colour not taken into } \\
\text { account in determining colour of } \\
\text { base material }\end{array}$ & Remake using suitable base material \\
\hline
\end{tabular}

